\title{
APPLICATION OF SYNTHETIC TAXONOMIC MEASURE TMAI FOR THE ASSESSMENT OF INVESTMENT ATTRACTIVENESS OF THE SELECTED FOOD INDUSTRY COMPANIES LISTED ON THE WARSAW STOCK EXCHANGE IN THE YEARS 2013 - 2016
}

Monika ZIELIŃSKA-SITKIEWICZ, Faculty of Applied Informatics and Mathematics, Warsaw University of Life Sciences SGGW, Ul. Nowoursynowska 166, 02-787 Warsaw, Poland, monika_zielinska_sitkiewicz@sggw.pl (corresponding author)

Mariola CHRZANOWSKA, Faculty of Applied Informatics and Mathematics, Warsaw University of Life Sciences - SGGW, Ul. Nowoursynowska 166,02-787 Warsaw, Poland, mariola_chrzanowska@sggw.pl

\begin{abstract}
The food sector is one of the most important and fastest growing branches of the Polish economy. It employs almost $15 \%$ of all employees employed in the industry. Polish manufacturers are characterised by high competitiveness both in the EU and in the world. The macroeconomic environment in recent years has been relatively stable for the development of the food industry production in Poland, but the dynamics of agricultural-food products has experienced a slight slowdown. There were also fluctuations in profitability ratios in the sector, which may have been somewhat alarming for the investors. The article attempted to evaluate the investment attractiveness of 24 joint stock companies in the food sector, representing various industries, listed on the Warsaw Stock Exchange. The Taxonomic Measure of the Attractiveness of Investments (TMAI) and the company rankings were created for the years $2013-$ 2016. The results showed that the Wawel and Astarta companies were at the top of the rankings in the studied years, representing the confectionery and the sugar sector, and the Żywiec company from the beer industry. The meat and fish processing companies were more or less centred on the scale. The companies KSG Argo, Milkiland, Wilbo, Pepees and Pamapol involved in the agricultural-food production and processing received the poorest evaluations of the investment attractiveness.

The synthetic taxonomic TMAI measure makes it possible to build company rankings within the analyzed group, from the point of view of the assessment of the financial condition and investment attractiveness of the surveyed companies. It can provide additional help in assessing the company's situation, e.g., for the investors.
\end{abstract}

Keywords: food industry companies, investment attractiveness, TMAI, taxonomic measure

\section{INTRODUCTION}

The food sector in Poland is interesting for investors because the Polish economy is growing considerably thanks to consumption. The food industry companies therefore offer exposure to the industry, which stands behind the Polish economic growth. According to the Polish Investment and Trade Agency, the food sector is one of the most important and the fastest growing branches of the Polish economy, and Poland is the $6^{\text {th }}$ largest market in Europe, with a potential of 38,5 million inhabitants. Polish food manufacturers are characterised by high competitiveness both in the European Union and in the world. Most of the food industry export goes to the internal market of the Union each year, which after accession has also become one of the main driving forces for the food sector. In July 2014, the food industry was drawn to the list of priority sectors for the Polish government. As a result, Polish companies in the processing industry, intending to develop their business or establish new production centres, can count on government grants or take advantage of tax relief in one of the 14 specially prepared economic zones. The strength of the Polish food industry is: the long tradition, high quality products, competitive manufacture and labour costs, well-developed network of suppliers, solid educational base, and consequently, a well-qualified personnel.

When analyzing the dynamics of the food industry production year after year, an upward tendency can be observed in the recent years. Although in 2014 the food industry in Poland maintained its production at roughly the same level as in the previous year, but in 2015 it increased by 3,6\%, and in 2016 it increased by 6,4\%. Out of three major divisions of the food industry, the development of food products manufacture was the most stable. The production of beverages was stagnant, and in the tobacco industry the value of the sold production was growing due to the raise in exports of tobacco products (Figure 1).

Copyright (C) 2017 The Authors. Published by Aleksandras Stulginskis University. This is an open-access article distributed under the terms of the Creative Commons Attribution License (CC-BY 4.0), which permits unrestricted use, distribution, and reproduction in any medium, provided the original author and source are credited. 


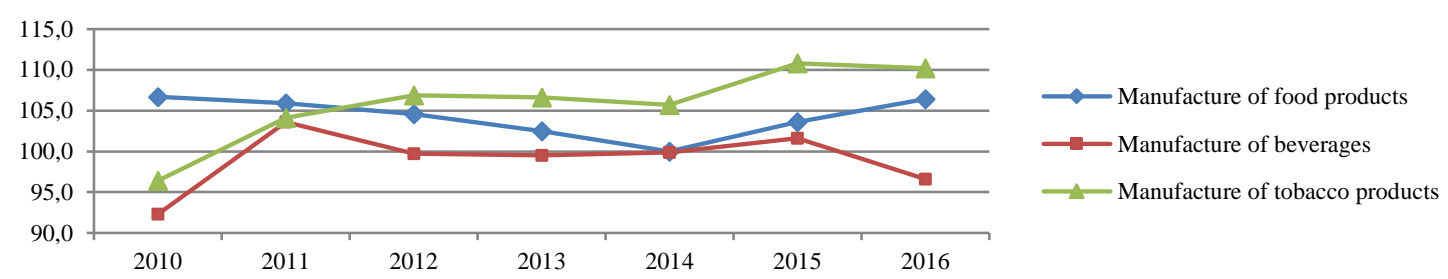

Source: own elaboration based on the data of the Central Statistical Office of Poland (GUS), Outlays and results in industry - reports Figure 1. Food, beverages and tobacco production index (in constant prices)

Food producers have achieved good financial results in recent years, while increasing turnover. The income from sales in the whole sector in the years 2010-2016 increased on average by almost 5\% per year. After a short-term decline in 2014, the analysis of annual sales revenue indicates an increase in the dynamics of the food industry in the last two years (Table 1and 2). The export of food products had a significant impact on the growth of food industry production in recent years, the dynamics of which has clearly slowed down recently.

Table 1. Net sales revenues in mln PLN

\begin{tabular}{|c|c|c|c|}
\hline Sector of food industry & 2014 & 2015 & 2016 \\
\hline & 166264,1 & 165946,5 & \\
\hline Manufacture of food products & 0 & 0 & 178390,80 \\
\hline Manufacture of beverages & 29011,50 & 29726,40 & 29386,50 \\
\hline $\begin{array}{r}\text { Manufacture of tobacco } \\
\text { products }\end{array}$ & 11590,00 & 12146,20 & 12347,50 \\
\hline
\end{tabular}

Source: own elaboration based on the data of the GUS, Outlays and results in industry - reports

Table 2.Revenues from export in mln PLN

\begin{tabular}{|c|c|c|c|}
\hline Sector of food industry & 2014 & 2015 & 2016 \\
\hline & 40246,5 & 42777,0 & 48151,1 \\
\hline Manufacture of food products & 0 & 0 & 0 \\
\hline Manufacture of beverages & 1585,60 & 2617,10 & 2702,40 \\
\hline $\begin{array}{r}\text { Manufacture of tobacco } \\
\text { products }\end{array}$ & 1560,40 & 1570,80 & 2012,00 \\
\hline
\end{tabular}

Source: own elaboration based on the data of the GUS, Outlays and results in industry - reports

In 2012-2013, the growth rate of the export of agricultural and food products was $17,5 \%$ and $14,2 \%$ per year, respectively, in $20147,1 \%$, and in 2015 9,2\% per year. However, in 2016 the sales of food products to foreign markets increased by approx. $2 \%$ (Figure 2).

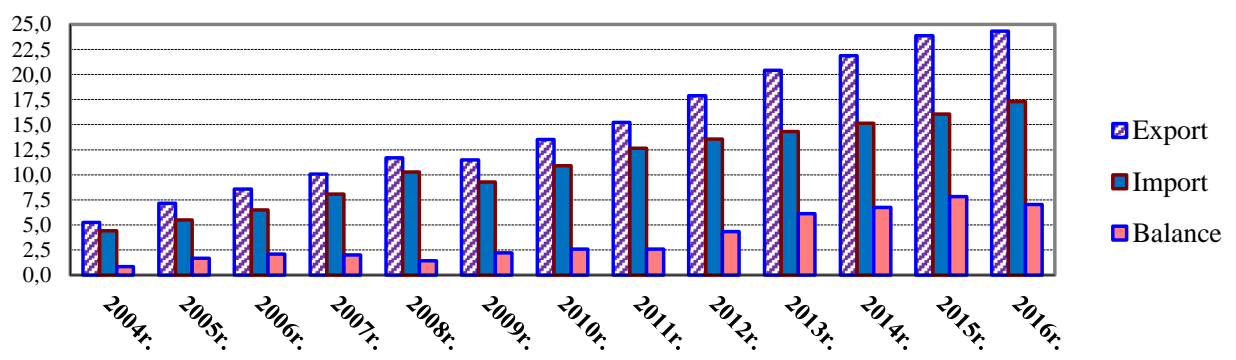

Source: own elaboration based on the data of the Ministry of Agriculture and Rural Development and the GUS

Figure 2. Trade in agri-food products in the years $2004-2016$

According to the data from the Ministry of Agriculture and Rural Development and the Central Statistical Office of Poland (GUS), in 2016 the value of export of agricultural and food products amounted to $24332 \mathrm{mln}$ euro, which represented an increase of 1,9\% compared to the previous year. Sales to the European Union countries (UE-28) increased by $0,9 \%$, and a total of $19822 \mathrm{mln}$ euro worth goods were sold to the EU market. In the structure of agricultural and food export, the share of EU countries compared to 2015 dropped from 82,3\% to 81,5\% (Figure 3). The highest number of agricultural and food products was sold in 2016 to Germany (22,6\% share in the whole agricultural and food export). Great Britain was on the second place among the recipients of the Polish agricultural and food products $(9 \%$ share in the export), the Czech Republic was on the third place (6,7\% share in the export), and the Netherlands on the fourth place (5,6\% share in the export). The value of export to all EU countries in billion euro is presented in Figure 4 . The value of export to the Commonwealth of Independent States (CIS) amounted to $171 \mathrm{mln}$ euro in 2016, and in comparison to 2015 it increased by $5,9 \%$. The sale of agricultural and food products to CIS countries in 2016 constituted $4,8 \%$ of the total value of the whole export of agricultural and food products and was higher than last year (4,6\%). The Russian Federation, which was a traditional market for selling agricultural products, due to the embargo, in 2015 was on the $14^{\text {th }}$ place among the largest recipients of Polish food, while in 2016 it fell to the $16^{\text {th }}$ position. The sales value to the Russian market fell by $5,6 \%$ to the level of $376 \mathrm{mln}$ euro.

On the basis of the GUS data on expenditure and results of the food industry and the analyses of the Institute of Agricultural and Food Economics - National Research Institute, it can be stated that in the last five years the profitability ratios in the food industry companies were growing. In 2016, the net profit margin exceeded 4,5\% of revenues, and profitability of equity amounted to $12,8 \%$. This level of ratios can be described as high, as operating income was over $9 \%$ higher than operating expenses. The systematic improvement of the current financial liquidity ratio in the food industry companies allowed for increasing the share of own funds in financing the current assets of these companies. Greater investment activity in the sector has increased the level of long-term debt over the last four years. Moreover, in the years 2013-2016 all food industries had the capacity to generate profits. The cumulative financial results in each of them was positive. The highest profitability was achieved 
in the confectionery and beer industry, and the lowest in oil, dairy, poultry and meat industries. The biggest fluctuations in this indicator have been observed in the spirits industry (Drożdż, Mroczek, 2017).

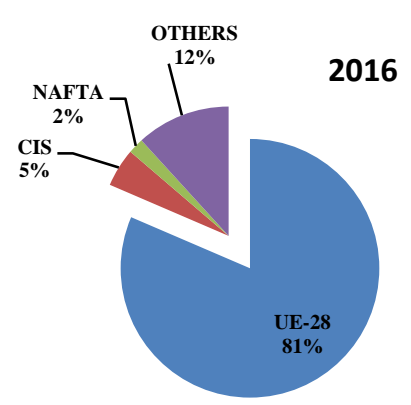

Source: own elaboration based on the data of the Ministry of Agriculture and Rural Development and the GUS

Figure 3. Export structure of agri-food Products in $2016(\%)$

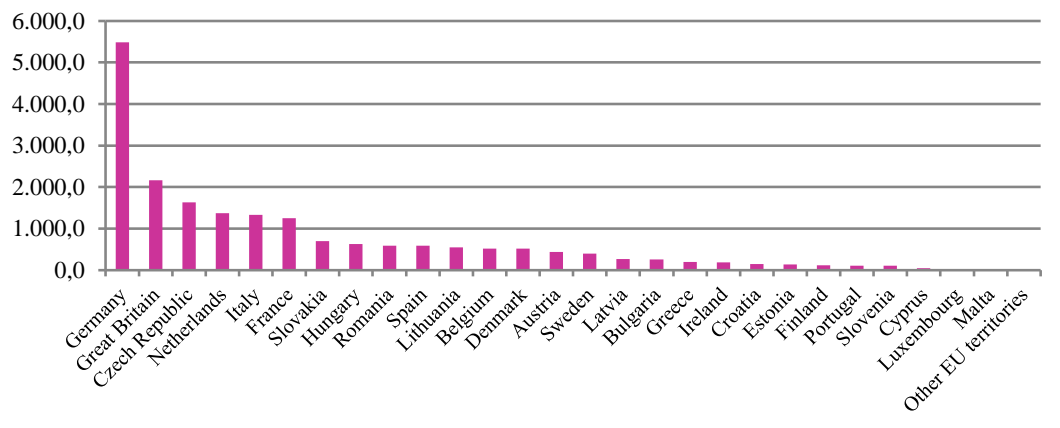

Source: own elaboration based on the data of the Ministry of Agriculture and Rural Development and the GUS

Figure 4. Export value of agri-food products to EU countries (in billion euros)

Investment process on the stock market depends on many factors. Possibility of objectively asses the economic condition of stock companies is very relevant for investors. Based on this information they can build strategies using a variety of methods and take different investment decisions. Thus, professional assessment of the financial condition of stock companies becomes very significant and the need to use methods that can reduce the number of available variables and thereby improve the analysis of the stock market. Taxonomic synthetic measures belong to such methods. Classification of companies by synthetic development measure TMAI gives one of the best arrangement in terms of evaluation financial and economic conditions of stock companies.

\section{REASERCH METHODS}

The aim of the article is to compare the investment attractiveness of 24 food joint stock companies listed on the Warsaw Stock Exchange by building their ratings for the years 2013 - 2016 using the Taxonomy Measure of the Attractiveness of Investments (TMAI). The following companies were selected for the study: Agroton, AUGA Group AB, Ambra SA, Astarta Holding NV, Colian Holding SA, Graal SA, Imcompany SA, Indykpol SA, ZM Henryk Kania SA, Kernel Holding SA, Kofol, Kruszwica SA, KSG Agro SA, Makarony Polskie SA, Milkiland, Otmuchów SA, Ovostar Union, Pamapol SA, Pepees SA, Seko SA, Tarczyński SA, Wawel SA, Wilbo SA and Żywiec SA, which have been listed on the Warsaw Stock Exchange at least since 2013. The activity of the analysed companies is conducted both in Poland and abroad. They represent different sectors of the food industry, such as: agricultural and food production and processing, sugar and confectionary production, oil, milk, meat, fish, egg product and pasta production and production of soft drinks and alcoholic beverages.

All studied companies were subjected to fundamental analysis. A group of eleven financial indicators for unfounded companies recommended by the literature was used for the construction of the synthetic Measure of Attractiveness of the Investment (TMAI) (Łuniewska, Tarczyński, 2004, 2006). They characterise the most important aspects of the company activity: profitability $(R O E, R O A, R O S)$, liquidity $(C R)$, efficiency $(I T R, L R, A T R, R T R)$, debt $(D R)$ and the company's economic situation on the stock market (P/E, P/BV). Table 3 presents the formulas for calculating the selected indicators and their impact on the general criterion.

Table 3.The selection of variables and their impact on the general criterion

\begin{tabular}{|c|c|c|}
\hline Ratio & Formula & $\begin{array}{l}\text { The impact on } \\
\text { the general criterion }\end{array}$ \\
\hline Return on Equity (ROE) & Net Income / Shareholder Equity & stimulant \\
\hline Return on Assets (ROA) & Net Income / Average Total Assets & stimulant \\
\hline Return on Sale (ROS) & Net Income / Sales Revenue & stimulant \\
\hline Inventory Turnover Ratio (ITR) & Net Sales / Average Inventory & stimulant \\
\hline Liabilities Ratio $(L R)$ & 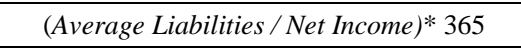 & stimulant \\
\hline Asset Turnover Ratio (ATR) & Net Sales Revenue / Average Total Assets & stimulant \\
\hline Receivable Turnover Ratio (RTR) & Sales Revenue/ Average Receivables & nominant $(7-10)$ \\
\hline Current Ratio $(C R)$ & Current Assets / Current Liabilities & nominant $(1,0-1,2)$ \\
\hline Debt Ratio $(D R)$ & Total Liabilities / Total Assets & nominant $(57 \%-67 \%)$ \\
\hline Price Earnings Ratio $(P / E)$ & Market Value per Share/ Earnings per Share & stimulant \\
\hline Price to Book Ratio $(P / B V)$ & $\begin{array}{c}\text { Market Price per Share / Book Value per } \\
\text { Share }\end{array}$ & stimulant \\
\hline
\end{tabular}

Source: own elaboration based on papers by Tarczyński and Łuniewska, 2006 
In the first stage of the study, all variables were transformed in the standardization process for determining the value of the TMAI measure. Due to the specificity of variables Current Ratio $(C R)$, Debt Ratio $($ DR) and Receivable Turnover Ratio $(R T R)$ were individually transformed from nominants into stimulants. A detailed description of the criteria for normalization of variables and transformations of indicators into stimulants was presented in the works by Walesiak (2004, 2014) and Zielińska-Sitkiewicz (2017).

In the second stage of the study, according to the procedure described by Tarczyński and Łuniewska (2005, 2017), the Taxonomic Measure of Attractiveness of the Investment was determined for each analysed period, where the distance of each object is calculated from the pattern, taking into account the different influence power of the financial ratios on the analysed investment attractiveness of the companies. The formula for calculating the distance from the pattern is as follows:

$$
d_{i}=\sqrt{\sum_{j=1}^{m} w_{j}\left(z_{i j}-z_{0 j}\right)^{2}}, \quad(i=1,2, \mathrm{~K}, n)
$$

$z_{i j}$ - standardized value of the attribute $j$ for the object $i$,

$z_{0 j}$ - maximum value of $z_{i j}$ for the object $i$.

In order to calculate the weighing system for financial indicators, the following formula based on coefficient of variation of the variable can be used:

$$
w_{j}=\frac{V_{j}}{\sum_{j=1}^{m} V_{j}}, \quad(j=1,2, \mathrm{~K}, m)
$$

The following formula is used to determine the TMAI measure based on the given distance from the pattern:

$$
\text { TMAI }_{i}=1-\frac{d_{i}}{d_{0}}, \quad(i=1,2, \mathrm{~K}, n)
$$

$T M A I_{i}$ - synthetic measure for the object $i$,

$d_{i}$ - distance between the object $i$ and pattern object,

$d_{0}$ - norm assuring that $T M A I_{i}$ reaches values ranging from 0 to 1 calculated according to the formula:

$$
d_{0}=\bar{d}+k \cdot S_{d}
$$

$\bar{d}$ - average value of $d_{i}$

$S_{d}$ - standard deviation of $d_{i}$

and $k$ is the constant determined as:

$$
k \geq \frac{d_{i \max }-\bar{d}}{S_{d}}
$$

$d_{\text {imax }}$ - is the maximum value of $d_{i}$.

\section{REASERCH RESULTS}

Table 4 shows the results of the TMAI measure, and Table 5 shows the rankings for all surveyed companies. The following markings were adopted for labelling the analysed classifications in the years 2013-2016:

\begin{tabular}{|l|l|}
\hline & - companies ranked the highest in the ranking of individual years \\
\hline & - companies with average positions in the ranking of individual years \\
\hline & - companies ranked the lowest in the ranking of individual years \\
\hline
\end{tabular}

$\uparrow 1$ or $\downarrow-1$ - the increase or decrease in the ranking by 1 position compared to the previous year; $\uparrow 0$ - unchanged; the bold font was used for marking the results for 3 best companies an 3 companies from the end of the ordering.

In all rankings in the analyzed years, the following companies were ranked the highest: Żywiec SA, Wawel SA and Ovostar Union. These companies were characterised by high profitability of equity, good profitability on sales, moderate debt and a high degree of current assets in relation to short-term liabilities. The Astarta Holding NV company has significantly improved its rating in the classification of the investment attractiveness from 2013 to 2016 . This was affected by the very good profitability results of the company thanks to a high net profit generated in 2016 . The sales structure of the companies: Żywiec SA and Wawel SA, manufacturers of finished goods, indicates a high share of sales in Poland - over 90\%. While the Ovostar Union and Astarta Holding NV companies sell most of their products (semifinished products) in Ukraine, respectively 69\% and 49\%, and they increase their sales in the EU and Asia dynamically. The poorest ratings were obtained by the following companies: KGS Agro SA, Milkiland, Wilbo SA and Pamapol SA. These companies showed a low return on equity in the analysed period and a very low sales profitability and property profitability. The KGS Agro SA company had recorded negative equity in the years 2014 - 2016, which resulted due to high losses recorded in 2013 and 2014. The Milkiland holding significantly reduced its equity (from 170 mln to approx. $6 \mathrm{mln}$ PLN) recording a total loss of $183 \mathrm{mln}$ PLN in the years 2014-2016. 
Table 4. Results of the TMAI measure of the studied companies for years 2013-2016

\begin{tabular}{|l|l|r|r|r|r|}
\hline \multicolumn{1}{|c|}{ FIRM } & \multicolumn{1}{|c|}{ TRADE } & $\mathbf{2 0 1 6}$ & $\mathbf{2 0 1 5}$ & $\mathbf{2 0 1 4}$ & $\mathbf{2 0 1 3}$ \\
\hline Agroton & agro-food production and processing & 0,3002 & $\mathbf{0 , 2 0 3 3}$ & $\mathbf{0 , 1 2 0 0}$ & $\mathbf{0 , 2 3 6 3}$ \\
\hline AUGA Group AB & agro-food production and processing & 0,2598 & 0,3707 & $\mathbf{0 , 5 1 2 0}$ & 0,3892 \\
\hline Ambra & wine industry & 0,2230 & 0,3274 & 0,3940 & 0,3439 \\
\hline Astarta & sugar industry & 0,3340 & 0,3724 & 0,3658 & 0,3775 \\
\hline Colian & confectionery industry & 0,2087 & 0,3404 & 0,3834 & 0,3028 \\
\hline Graal & fish industry & 0,2152 & 0,2910 & 0,3816 & 0,2955 \\
\hline Imcompany & dairy industry & 0,3014 & 0,3822 & 0,3632 & 0,3938 \\
\hline Indykpol & meat industry & 0,2081 & 0,3627 & 0,4280 & 0,2849 \\
\hline Kania & meat industry & 0,2196 & 0,3422 & 0,4119 & 0,3549 \\
\hline Kernel & oil industry & 0,2986 & 0,4303 & 0,4278 & 0,2582 \\
\hline Kofol & Non-alcoholic beverage industry & 0,2516 & 0,3782 & 0,4112 & 0,2931 \\
\hline Kruszwica & oil industry & 0,2726 & 0,3632 & 0,4414 & 0,3828 \\
\hline KSG Agro & agro-food production and processing & $\mathbf{0 , 0 0 4 7}$ & $\mathbf{0 , 0 9 7 3}$ & $\mathbf{0 , 0 0 0 0}$ & $\mathbf{0 , 0 0 0 0}$ \\
\hline Makarony Polskie & egg products industry, pasta & 0,2133 & 0,3245 & 0,3901 & 0,2975 \\
\hline Milkiland & dairy industry & $\mathbf{0 , 0 0 0 0}$ & $\mathbf{0 , 0 0 0 0}$ & $\mathbf{0 , 3 0 7 1}$ & 0,3357 \\
\hline Otmuchów & confectionery industry & $\mathbf{0 , 0 2 9 4}$ & 0,3066 & 0,3914 & 0,3006 \\
\hline Ovostar Union & industry egg products & $\mathbf{0 , 3 6 9 6}$ & $\mathbf{0 , 5 2 9 0}$ & 0,4889 & $\mathbf{0 , 4 8 0 5}$ \\
\hline Pamapol & agro-food production and processing & 0,1849 & 0,2981 & 0,3732 & $\mathbf{0 , 1 8 5 8}$ \\
\hline PEPEES & agro-food production and processing & 0,2325 & 0,3135 & 0,3793 & 0,2771 \\
\hline Seko & fish industry & 0,2091 & 0,3239 & 0,3918 & 0,3281 \\
\hline Tarczyński & meat industry & 0,2028 & 0,3370 & 0,4001 & 0,3221 \\
\hline Wawel & confectionery industry & $\mathbf{0 , 4 9 7 6}$ & $\mathbf{0 , 5 9 5 3}$ & $\mathbf{0 , 7 1 0 8}$ & $\mathbf{0 , 6 1 7 0}$ \\
\hline Wilbo & fish industry & 0,1309 & 0,2972 & 0,3764 & 0,2918 \\
\hline Żywiec & brewing industry & $\mathbf{0 , 6 5 7 4}$ & $\mathbf{0 , 6 7 2 2}$ & $\mathbf{0 , 6 3 4 3}$ & $\mathbf{0 , 7 0 6 2}$ \\
\hline Source: own calculation & & & &
\end{tabular}

Table 5. Results of the TMAI ranking of the studied companies for years 2013-2016

\begin{tabular}{|c|c|c|c|c|c|}
\hline FIRM & TRADE & 2016 & 2015 & 2014 & 2013 \\
\hline Agroton & agro-food production and processing & $6 \uparrow 16$ & $22 \uparrow 1$ & $23 \downarrow-1$ & 22 \\
\hline AUGA Group AB & agro-food production and processing & $9 \downarrow-1$ & $8 \downarrow-5$ & $3 \uparrow 2$ & 5 \\
\hline Ambra & wine industry & $12 \uparrow 2$ & $14 \downarrow-3$ & $11 \downarrow-2$ & 9 \\
\hline Astarta & sugar industry & $4 \uparrow 3$ & $7 \uparrow 13$ & $20 \downarrow-13$ & 7 \\
\hline Colian & confectionery industry & $17 \downarrow-5$ & $12 \uparrow 3$ & $15 \downarrow-2$ & 13 \\
\hline Graal & fish industry & $14 \uparrow 7$ & $21 \downarrow-5$ & $16 \uparrow 0$ & 16 \\
\hline Imcompany & dairy industry & $5 \uparrow 0$ & $5 \uparrow 16$ & $21 \downarrow-17$ & 4 \\
\hline Indykpol & meat industry & $18 \downarrow-8$ & $10 \downarrow-4$ & $6 \uparrow 13$ & 19 \\
\hline Kania & meat industry & $13 \downarrow-2$ & $11 \downarrow-3$ & $8 \uparrow 0$ & 8 \\
\hline Kernel & oil industry & $7 \downarrow-3$ & $4 \uparrow 3$ & $7 \uparrow 14$ & 21 \\
\hline Kofol & Non-alcoholic beverage industry & $10 \downarrow-4$ & $6 \uparrow 3$ & $9 \uparrow 8$ & 17 \\
\hline Kruszwica & oil industry & $8 \uparrow 1$ & $9 \downarrow-4$ & $5 \uparrow 1$ & 6 \\
\hline KSG Agro & agro-food production and processing & $23 \uparrow 0$ & $23 \uparrow 1$ & $24 \uparrow 0$ & 24 \\
\hline Makarony Polskie & egg products industry, pasta & $15 \uparrow 0$ & $15 \downarrow-1$ & $14 \uparrow 1$ & 15 \\
\hline Milkiland & dairy industry & $24 \uparrow 0$ & $24 \downarrow-2$ & $22 \downarrow-12$ & 10 \\
\hline Otmuchów & confectionery industry & $22 \downarrow-4$ & $18 \downarrow-5$ & $13 \uparrow 1$ & 14 \\
\hline Ovostar Union & industry egg products & $3 \uparrow 0$ & $3 \uparrow 1$ & $4 \downarrow-1$ & 3 \\
\hline Pamapol & agro-food production and processing & $20 \downarrow-1$ & $19 \uparrow 0$ & $19 \uparrow 4$ & 23 \\
\hline PEPEES & agro-food production and processing & $11 \uparrow 6$ & $17 \uparrow 0$ & $17 \uparrow 3$ & 20 \\
\hline Seko & fish industry & $16 \uparrow 0$ & $16 \downarrow-4$ & $12 \downarrow-1$ & 11 \\
\hline Tarczyński & meat industry & $19 \downarrow-6$ & $13 \downarrow-3$ & $10 \uparrow 2$ & 12 \\
\hline Wawel & confectionery industry & $2 \uparrow 0$ & $2 \downarrow-1$ & $1 \uparrow 1$ & 2 \\
\hline Wilbo & fish industry & $21 \downarrow-1$ & $20 \downarrow-2$ & $18 \uparrow 0$ & 18 \\
\hline$\dot{Z}$ 'ywiec & brewing industry & $1 \uparrow 0$ & $1 \uparrow 1$ & $2 \downarrow-1$ & 1 \\
\hline
\end{tabular}

Source: own calculation

\section{CONCLUSIONS}

The analyses show that the companies, listed on the Warsaw Stock Exchange, manufacturing beer, sugar, sweets and eggs enjoy the greatest investment attractiveness.

Examining the financial condition of the 24 food companies surveyed indicates that the application of the Taxonomic Measure of attractiveness of Investment makes it possible to assess the economic potential of the verified companies according to the results of the classification. One should bear in mind the subjectivism in the construction of taxonomic synthetic measures, which affects the layout of companies in the rankings. In subsequent stages of the 
algorithm, the researcher makes a number of decisions regarding the selection of a group of financial indicators, the way they are normalized, or the use of diverse weights. In the paper of M. Zielińska-Sitkiewicz (2015) there were proposed following weights for groups of indicators: profitability (ROE, ROA, ROS) - weight 0.2; efficiency (ITR, LR, ATR, RTR) - weight 0.05; liquidity (CR) - weight 0.1 and debt (DR) - weight 0.1 . Previous studies by Zielińska-Sitkiewicz on the classification of stock companies have shown that the weighting of financial ratios gave good results in the economic assessment of the examined enterprises.

The classification of companies in the analyzed industry can be supported by taking the expert knowledge into consideration, supported by the detailed financial analysis. The results of the rankings should not be the only tool in the assessment of the company's investment attractiveness against other companies from the given sector, but they can constitute an additional help in assessing the company's situation, e.g., for the investors.

\section{REFERENCES}

1. Central Statistical Office of Poland. Outlays and results in industry - reports from 2010 to 2016, www.stat.gov.pl (Accessed 31/09/2017)

2. Drożdż, J., Mroczek, R., 2017: Stable but diverse situation of sectors in food industry, Przemyst Spożywczy, T.71, No. 9 pp.6--11

3. Ministry of Agriculture and Rural Development, Agriculture and Food Economy in Poland - reports from 2013 to 2016 , http://www.minrol.gov.pl/eng/Reports-and-Publications/AGRICULTURE-AND-FOOD-ECONOMY-IN-POLAND (Accessed on 31/09/2017)

4. Ministry of Agriculture and Rural Development, Polish foreign trade in agri-food products in 2016, Public Information Bulletin https://bip.minrol.gov.pl/Informacje-Branzowe/Handel-zagraniczny-artykulami-rolno-spozywczymi/POLSKI-HANDELZAGRANICZNY-ARTYKULAMI-ROLNO-SPOZYWCZYMI-w-2016-r (Accessed on 31/08/2017)

5. Polish Investment and Trade Agency PFR Group, Why Poland, https://www.paih.gov.pl/why_poland (Accessed on 31/09/2017)

6. Tarczyński, W., Łuniewska, M., 2004: Dywersyfikacja ryzyka na polskim rynku kapitałowym, Placet, Warsaw.

7. Tarczyński, W., Łuniewska, M., 2005: Stability of Selected Linear Ranking Methods - An Attempt of Evaluation for the Polish Stock Market. In: Baier D., Wernecke KD. (eds) Innovations in Classification, Data Science, and Information Systems. Studies in Classification, Data Analysis, and Knowledge Organization. Springer, Berlin, Heidelberg, pp. 523-534

8. Tarczyński, W., Łuniewska, M., 2006: Metody wielowymiarowej analizy porównawczej na rynku kapitałowym, PWN, Warsaw

9. Tarczyński, W., Łuniewska, M., 2017: Efficiency of Investment with the Use of Fundamental Power Aspects. In: Nermend K., Latuszyńska M. (eds) Neuroeconomic and Behavioral Aspects of Decision Making. Springer Proceedings in Business and Economics. Springer, Cham pp. 159-173. https://doi.org/10.1007/978-3-319-62938-4_10

10. Walesiak, M., 2004: Decision problems in a cluster analysis procedure, Ekonometria, Vol. 13, pp. 55-59.

11. Walesiak, M., 2014: Data normalization in multivariate data analysis. An overview and properties, Przegląd Statystyczny, Vol. 4, pp. 363-372.

12. Zielińska-Sitkiewicz, M., 2015: An application of selected synthetic measures for classification of building materials companies listed on the Warsaw Stock Exchange. Zeszyty Naukowe Uniwersytetu Szczecińskiego. Finanse. Rynki Finansowe. Ubezpieczenia, No 862(75), pp. 577-588.

13. Zielińska-Sitkiewicz, M., 2017: Classification of selected food industry companies listed on the Warsaw Stock Exchange - the impact of normalization procedures, Proceedings of the 2017 International Conference "Economic Science for Rural Development", No. 46, pp. 359-366, Jelgava 